aneurysm, assessment of the contractile segment, and differentiation from diffuse left ventricular hypokinesis. ${ }^{13} 15$ A giant aneurysm of the anterior wall may be incorrectly diagnosed, however - an error made less likely by additional scintigraphic views and two dimensional echocardiography. ${ }^{16}$

Untreated, patients with a left ventricular aneurysm have a $90 \%$ chance of dying within five years of their myocardial infarction. ${ }^{17}{ }^{18}$ Such global figures must be qualified by the statement that prognosis depends on several factors and, in particular, the overall left ventricular performance. Death usually results from recurrent myocardial infarction with or without left ventricular failure.

Patients should be referred for consideration of surgery when the maximum appropriate medical treatment has failed. ${ }^{19}$ All patients, especially those with severe left ventricular failure, must be fully assessed with attention paid to the function of the non-aneurysmal contractile segment of the left ventricle, the severity of occlusive coronary artery disease, and the presence and severity of mitral regurgitation. ${ }^{20}$ Both the variable operative mortality (4-50\%) and the clinical prognosis depend on these factors. ${ }^{21} 22$ Radionuclide angiography and two dimensional echocardiography are playing an increasing part in the preoperative (and postoperative) assessment of left ventricular function. ${ }^{23}$

Many patients with severe left ventricular failure are much relieved after combined aneurysmectomy and coronary artery bypass surgery. ${ }^{19} 24$ Some, however, have disappointing results despite apparently good contraction of the nonaneurysmal segment on preoperative assessment. Indeed, a paradoxical inverse relation has been reported between the extent of any improvement in postoperative left ventricular function and the function of the remaining viable segments. ${ }^{25}$ In patients who are not in failure aneurysmectomy with coronary artery bypass for refractory angina carries a low operative mortality $(4 \%)$ and a five year survival of about $75 \% .{ }^{26}$

Mural thrombi are present in about half of all left ventricular aneurysms. The incidence of clinically recognised embolism is low at $5 \%$, but necropsy studies show a higher incidence, of about $30 \% .{ }^{27}$ The presence of mural thrombus correlates inversely with the duration of treatment with anticoagulants, and the effect of anticoagulants should be assessed before considering aneurysmectomy for peripheral embolism.

Aneurysmectomy for ventricular tachyarrhythmias may help many patients, but the results are unpredictable, and the operative mortality approaches $60 \%$ within a month of acute myocardial infarction. ${ }^{192}$ The site of origin of such arrhythmias may be distant from the aneurysm. Electrophysiological mapping may help in its location: an encircling ventriculotomy or endomyocardial resection may then be beneficial. ${ }^{29}$ Clearly a thorough trial of medical treatment should be given before surgery.

What has emerged from recent research is that patients with left ventricular aneurysms after myocardial infarction form a heterogeneous group. The main determinant of the clinical course and outcome of surgery is the state of the coronary arteries, which in turn determines the function of the non-aneurysmal segment of the left ventricle and the size of the left ventricular aneurysm. More studies of clearly defined subgroups of these patients are needed.

David A TibButt

Consultant Physician

Worcester Royal Infirmary,

Worcester WR1 3AS
Edwards JE. An atlas of acquired diseases of the heart and great vessels. Vol II. Philadelphia: WB Saunders, $1961: 615-29$

Med 1967;42:512-3

Lee DCS, Johnson RA, Boucher CA, Wexler LF, McEnany TM. Angiographic predictors of survival following left ventricular aneurysmectomy. Circulation 1977;56(suppl 2):12-8.

Oliveira JSM, de Oliveira JAM, Frederique U, Filho ECL. Apical aneurysms of Chagas's heart disease. Br Hear $\mathrm{f}$ 1981;46:432-7.

itchett DH, Kanji M. Mitral subannular left ventricular aneurysm. Br Heart J 1983;50:594-6. Goldberg MJ. Left ventricular aneurysm. Br J Hosp Med 1982;27:143-54.

sser CA, Kan G, David GK, Lie KI, Durrer D. Echocardiographic-cineangiographic correlation in detecting left ventricular aneurysm: a prospective study of 422 patients. Am $\mathcal{J}$ Cardio

${ }^{8}$ Graber JD, Oakley CM, Pickering BN, Goodwin JF, Raphael MJ, Steiner RE. Ventricular neurysm: an appraisal of diagnosis and surgical treatment Br $H$ eart $\mathcal{f} 1972 \cdot 34: 830-8$.

1972;29:1-6.

10 Walker WE, Stoney WS, Alford WC, Burrus GR, Glassford DM, Thomas CS. Results of surgical

management of acute left ventricular aneurysms. Circulation 1980;62(suppl 1):75-8.
11 Baur HR, Daniel JA, Nelson RR. Detection of left ventricular aneurysms on two dimensional echocardiography. Am J Cardiol 1982;50:191-6.

${ }^{12} \mathrm{Hall}$ RJC. M-mode echocardiography in the detection of surgically resectable left ventricular aneurysm. Eur Hean f 1983;4:230-7.

Winzelberg GG, Strauss HW, Bingham JB, McKusick KA. Scintigraphic evaluation of left ventricular aneurysm. Am $\mathcal{f}$ Cardiol 1980;46:1138-43.

4 Gatewood RP, Nanda NC. Differentiation of left ventricular pseudoaneurysm from true aneurysm with two dimensional echocardiography. Am $\mathcal{F}$ Cardiol 1980;46:869-78.

Erlebacher JA, Becker LC, Weiss JL, Leitl GP, Achuff SC, Fortuin NJ. Clinical recognition of giant left ventricular aneurysm. Am $\mathcal{F}$ Med 1981;71:799-805.

Dymond DS, Stephens J, Stone D, et al. Assessment of function of contractile segments in patients withleft ventricular

Mourdjinis A, Olsen E, Raphael MJ, Mounsey JPD. Clinical diagnosis and prognosis of ventricular aneurysms. Br Hear $\mathcal{F}$ 1968;30:497-513.

18 Nagle RE, Williams DO. Natural history of ventricular aneurysm without surgical treatment. $B r$ Hear $\mathcal{f}$ 1974;36:1037.

${ }^{19}$ Cohen M, Packer M, Gorlin R. Indications for left ventricular aneurysmectomy. Circulation 1983;67:717-22.

${ }^{20}$ Gold FL, Sharmer B, Hodges M, Helseth HK. Combined left ventricular aneurysmectomy, mitral valve replacement and aortocoronary bypass grafting: results of surgery. Circulation 1980; 62(suppl 1):147-52.

${ }^{21}$ Najafi $\mathrm{H}$, Meng $\mathrm{R}$, Javid $\mathrm{H}$, et al. Postmyocardial infarction left ventricular aneurysm. Cardiovasc

Brawley RJ, Magovern GJ, Gott VC, Donahoo JS, Gardner TJ, Watkins L. Left ventricular aneurys $85.712-7$

3 Froehlich RT, Falsetti HL, Doty DB, Marcus ML. Prospective study of surgery for left ventricular aneurysm. Am $\mathcal{F}$ Cardiol 1980;45:923-31.

${ }^{24}$ Borer JS, Jacobstein JG, Bacharach SL, Green MV. Detection of left ventricular aneurysm and evaluation of effects of surgical repair; the role of radionuclide cineangiography. Am $\mathcal{f}$ Cardiol 1980;45:1103-6.

${ }^{25}$ Stephens JD, Dymond DS, Stone DL, Rees GM, Spurrell RAJ. Left ventricular aneurysm and congestive heart fallure; value of exercise stress and isosorbide dinitrate in predicting

demodynamic results of aneurysmectomy. Am $\mathcal{J}$ Cardiol 1980;45:932-9.
${ }^{26}$ Rittenhouse EA, Sauvage LR, Mansfield PB, et al. Results of combined left ventricular aneurysmectomy and coronary artery bypass: 1974 to 1980 . Am $\mathcal{f}$ Surg 1982;143:575-8.

Reeder GS, Lengyel M, Tajik AJ, Seward JB, Smith HC, Danielson GK. Mural thrombus in left ventricular aneurysm. Mayo Clin Proc 1981;56:77-81.

da AJ, Stinson EB, Harrison DC. Surgery for life-threatening ventricular tachyarrhythmias. Am Cardiol 1979;44:1171-7.

Harken AH, Horowitz LN, Josephson ME. Comparison of standard aneurysmectomy and

neurysmectomy with directed endocardial resection for the treatment of recurrent sustained
ventricular tachycardia. F Thorac Cardiovasc Surg 1980;80:527-34.

\section{Deputising services}

Facts have been in short supply during the recent debate on problems associated with deputising services in general practice-but opinion has abounded and has at times been based on wishful thinking. If rational decisions on future policy are to be made the facts need to be distinguished and recognised.

Evening, night, and weekend visits make up only $1 \%$ to $3 \%$ of general practice consultations, ${ }^{1-3}$ but they arouse strong emotions in both doctors and patients. ${ }^{4}$ Over $40 \%$ of night visits are currently carried out by deputising services. ${ }^{5}$ When a call has been received deputising services usually respond by visiting the patient. ${ }^{67}$ General practitioners are much more likely to respond with telephone advice. ${ }^{1-3} \mathrm{~A}$ paper by Sheldon and Harris ( $p$ 474) confirms a previous report that use of deputising services was associated with a substantial increase in night visiting. ${ }^{8}$ No evidence exists to suggest which approach to calls represents good clinical practice.

On the whole, those deputising services which have been studied appear to respond to calls reasonably quickly. ${ }^{69}$ The appropriateness of delays is, however, difficult to judge from published work: patients are more likely to complain that the delay in visiting has been longer, ${ }^{10-12}$ or longer than 
they thought appropriate, ${ }^{12-14}$ when visited by a doctor who was not from their practice. When asked about satisfaction with the medical care provided patients are more likely to express dissatisfaction with a deputising doctor than with one from their own practice. ${ }^{12}$ is Few patients actually express a preference for a deputising service. ${ }^{1617}$

Clearly the public image of deputising services needs to be improved, but do they provide an inadequate standard of care? Some deputising services have employed staff with inappropriate experience, ${ }^{18}$ and there is anecdotal evidence of poor quality care from overworked deputies. ${ }^{19}$ Stevenson, however, visited a series of 57 patients after the visit of the deputy and judged the care provided to have been satisfactory. ${ }^{9}$ Referrals to hospital from deputising services appear no less appropriate than referrals from general practitioners, ${ }^{2021}$ and deputising services have not been thought to contribute substantially to the increasing workload of casualty departments. ${ }^{22}$

Some problems might be expected from the loss of continuity of care with deputising-compliance with antibiotics, for instance, is greater if the patient knows the prescribing doctor ${ }^{23}{ }^{24}$ - but the effects have not been quantified. Nor are there data on the effect on care of having the medical records at night, though there are circumstances (for example, in managing a confused old lady or an unconscious young woman) where ready access to the notes would clearly be valuable.

Doctors have mixed attitudes to deputising services. Cartwright and Anderson found that $52 \%$ of doctors saw deputising services as a disadvantage for patients. ${ }^{17}$ In a survey commissioned by the British Medical Association and Air Call, $82 \%$ of doctors "who used an outside arrangement" found the care provided satisfactory. ${ }^{25}$ On the other hand, in Wakeford's survey ${ }^{26} 47 \%$ out of 331 general practitioners "supported or tended to support" the minister's original suggestion that large partnerships should stop using deputising services completely. ${ }^{27}$

What has become clear is that there is substantial concern about deputising services both from within and without the profession. The standard of the least good deputising services must be improved, and this change is likely to be encouraged by the inclusion of lay members in the new Family Practitioner Committee deputising subcommittees -an innovation not welcomed by the recent annual conference of local medical committees. Nevertheless, the conference reiterated that deputising services and the doctors working for them should be of "high quality." 28

Ten years ago most deputising doctors seemed to be hospital doctors, ${ }^{18} 29$ but more recent reports indicate that over three quarters of deputies in many services are local general practitioners. ${ }^{25}{ }^{30} \mathrm{An}$ extension of the participation of local general practitioners in commercial deputising is described by Bain (p 471), who outlines the Portsmouth deputising service in which the professional advisory committee has stipulated that all doctors using the service should be participants, with the result that $90 \%$ of deputies are practising general practitioners. This arrangement is very similar to a large cooperative and ensures a reasonable standard of deputy while at the same time giving doctors greater flexibility to arrange time off duty. This type of arrangement is particularly suitable in the inner city, where primary care services are less organised ${ }^{31}$ but where medical and social need is particularly high. ${ }^{32}$ It may also suit doctors in small practices who are less able to arrange cover within their own practice than those in larger groups.

The within practice rota still provides better access to medical records and increased knowledge of the patient (especially difficult and regular callers) than does a deputising service. These are tangible benefits for the visiting doctor-and are seen as such by patients, who clearly prefer a visit from their own doctor or one of his partners. ${ }^{12-17}$ Once substandard deputising services are a thing of the past the argument over whether deputising detracts from good patient care will settle on this issue of continuity of care. When patients are ill out of hours, is it important that a doctor from their own practice calls, or will any competent doctor do? Is continuity of care a fundamental feature of general practice, or is it a luxury to be found only during the doctor's office hours?

Martin Roland

General Practitioner,

Cambridge CB5 8HB

1 Crowe MGF, Hurwood DS, Taylor RW. Out of hours calls in a Leicestershire practice. Br Med J 1976;: 1582-4.

fours calls in general practice: does the doctor's attitude alter patien ? Br Med 7 1983:287:28-30.

Tulloch AJ. Out of hours calls in an Oxfordshire practice. Practitioner 1984;228:663-6. Clyne MB. Night calls. London: Tavistock Publications, 1961.

Review Body on Doctors' and Dentists' Remuneration. 12th report. London: HMSO, 1982 Dixon RA, Williams BT. Twelve months of deputising: 100,000 patient contacts with eighteen services. Br Med J 1977; i: 560-3.

Naidoo AS. The doctor's deputising service in a single-handed practice. $f R$ Coll Gen Pract 1982;32:564-6.

8 Buxton $M J$ J, Klein RE, Sayers J. Variations in GP night visiting rates: medical organisation and consumer demand. Br Med $\mathcal{Y}$ 1977; i: $827-30$.

9 Stevenson JSK. Advantages of deputising services: a personal view. Br Med $\mathcal{F}$ 1982;284:947-8. 10 Royal Commission on the National Health Service. Report. London: HMSO, 1979

11 Ritchie J, Jacoby A, Bone M. Access to primary health care. London: HMSO, 1981 . Sawyer L, Arber S. Changes in
Br Med $\mathcal{f}$ 1982;284:1531-4.

Royal Commission on the National Health Service. Access to primany care: research report no 6

4 Welsh Consumer Council. Getting primary care on the NHS. Cardiff: Welsh Consumer Council, 1979.

15 Prudhoe RH. Deputising services. Br Med F 1984;288:718.

16 Muckle DS. Deputising services. Br Med f 1983:287:699.

17 Cartwright A, Anderson R. General practice revisited. London: Tavistock Publications, 1981.

Murray TS, Barber JH. The workload of a commercial deputising service. $f R$ Coll Gen Prac 1977;27:209-11.

19 Deer B. BMA guns for weekend rent-a-doctor firms. Sunday Times 1983 May 22:8 (cols 1-3). Williams BT, Dixon RA, Knowelden J. Emergency admissions to hospital from a deputising ervice: a controlled study of length of stay and outcome. British fournal of Preventive and Social Medicine 1973,27.126-8.

Comparison of the patient populations referred to the accident and emergency department outside working hours by general practitioners and their deputising services.

welden J. The impact of general practitioner deputising services A, 1973;23:638-45.

23 Charney E, Bynum R, Eldredge D, et al. How well do patients take oral penicillin?collaborative study in private practice. Pediatrics 1967;40:188-95.

24 Ettlinger PRA, Freeman GK. General practice compliance study: is it worth being a personal doctor? Br Med $\mathcal{F} 1981 ; 281: 1192-4$

25 British Medical Association/Air Call PLC. Out of hours patient care. London: British Medical Association, 1984

26 Wakeford R. Deputies: who needs them? World Medicine 1984 March 7: 17-9.

27 Department of Health and Social Security Health circular HC(FPY84) London: DHSS, 1984

28 Anonymous. Report of LMC conference. Br Med I 1984;289:61-2.

illiams BT, Dixon RA, Knov'elde: J. BMA deputising service in Sheffield, 1970. Br Med $\mathcal{f}$ 1973:i:593-9.

30 Consumer Association. Access to GPs. London: Consumer Association, 1983.

31 London Health Planning Consortium. Primary health care in inner London. London: LHPC,

1981. (Chairman: ED Acheson.)
32 Jarman B. A survey of primary care in London. J R Coll Gen Pract [Occas Pap] 1981;No 16. 